\title{
Heavy Minerals and Geochemical Characteristics of Sandstones as Indices of Provenance and Source Area Tectonics of the Ogwashi-Asaba Formation, Niger Delta Basin
}

\author{
0. Innocent Ejeh, I. Anthony Akpoborie, A. A. Israel Etobro \\ Department of Geology, Delta State University, Abraka, Nigeria \\ Email: tony.akpoborie@gmail.com
}

Received 8 July 2015; accepted 23 August 2015; published 26 August 2015

Copyright (C) 2015 by authors and Scientific Research Publishing Inc.

This work is licensed under the Creative Commons Attribution International License (CC BY). http://creativecommons.org/licenses/by/4.0/

(c) () Open Access

\section{Abstract}

Heavy mineral petrographic and geochemical compositions (major and trace/rare earth elements) of sandstones obtained from the Oligocene-Miocene Ogwashi-Asaba Formation, Niger Delta were studied to determine their provenance, source area weathering conditions and tectonic setting. The heavy mineral suite (opaque minerals, zircon, tourmaline, and rutile) revealed that the sandstones are mineralogically mature and implied rapid disintegration and chemical decomposition of sediments mostly of recycled orogen. The sandstones were geochemically classified as Fe-sand and partly quartz arenitic. Chemical Index of Alteration and Chemical Index of Weathering values of $89.92 \%$ and $\mathbf{9 1 . 8 7 \%}$ respectively suggest that the source region was predominantly felsic and was subjected to intense chemical weathering probably under tropical palaeoclimatic conditions with abundant rainfall that enhanced sediment recycling. Major element concentration discriminant plots also indicated that the sediments were derived from mixed sources (granitic, gneissic or recycled orogen) under passive margin setting. Chondrite normalized plot of the rare earth element pattern is marked by light rare earth element enrichment and negative Eu anomalies, interpreted to mean that provenance was mainly continental crustal rocks. Trace elemental ratios that are provenance diagnostic ( $\mathrm{La} / \mathrm{Sc}, \mathrm{Th} / \mathrm{Sc}, \mathrm{Cr} / \mathrm{Th}, \mathrm{La} / \mathrm{Co}, \mathrm{Th} / \mathrm{Co}, \mathrm{Th} / \mathrm{Cr}, \mathrm{Eu} / \mathrm{Eu}^{*}$, and $\mathrm{Eu}^{*}$ ) all point to sediments derived from felsic source and upper continental crust. The mixed provenance of the sandstones can be traced to the southwestern and southeastern Basement Complex (consisting of granites, gneisses, etc.) and sediments derived from the adjacent sedimentary basins (Anambra and Benue Trough). 


\section{Keywords}

\section{Provenance, Source Area Tectonics, Heavy Minerals, Geochemical Characteristics, Sandstones, Ogwashi-Asaba Formation, Niger Delta Basin}

\section{Introduction}

Provenance and other related studies associated with tectonic settings and palaeo-climatic conditions that determined weathering processes in the source areas of the Akata Formation, the Agbada Formation and Benin Formation that constitute the sedimentary fill of the Niger Delta Basin are lacking as emphasis has always been on the hydrocarbon potential of these formations. The lignite-bearing Ogwashi-Asaba Formation which is the surface equivalent of the Agbada Formation is no exception as only limited studies have specifically examined its hydrogeology [1]; aspects of the lignite geochemistry [2]; combined petrological, geochemical and sedimentological study [3]; and a textural and geochemical study for the determination of its depositional setting [4].

The primary objective of this investigation is to utilize heavy mineral and geochemical data to determine the provenance, tectonic setting of source area and palaeo-climatic conditions associated with the deposition of the Ogwashi-Asaba Formation. Similar research on provenance of siliciclastic sedimentary rocks has usually been focused on sandstones and has in the main been based on petrographic analysis of quartz, feldspars, micas and heavy minerals. However, ancillary techniques such as cathodoluminescence microscopy [5] and the geochemical studies of major, trace and rare earth elements and isotopes in siliciclastics have also been used. The use of heavy minerals (the components of siliciclastics whose specific gravity is greater than that of bromoform (2.8)) is a universally accepted method for determining the provenance of siliciclastics [6] [7] because they resist relatively the physiochemical alteration associated with source area weathering, erosion and diagenesis [8] and thus retain and bear the source rock characteristics from which they were derived.

Indeed, geochemical data from sandstones sequences deposited in various environments provide invaluable clues on ancient source area weathering conditions, variations in provenance compositions and tectonic settings [9]-[13]. The characteristic compositions of source rocks are also typically well recorded in the sedimentary fills which furnish valuable information about the type of source rocks and their tectonic setting [14]-[22].

\section{Geology and Stratigraphic Setting of the Niger Delta Basin}

Firs Adediran et al. [23] described the coastal sedimentary basins (Dahomey, Anambra, Niger Delta and Calabar Flank) of Nigeria as open-type, developed along the passive continental margin of the Gulf of Guinea and filled with continental deposits. The drifting apart of the South American continent from the African continent during the late Jurassic or early Cretaceous has been closely related to the spatial distribution of these basins [24]. The Niger Delta basin occupies the southern end of the Anambra basin that is adjacent to the Benue Trough, formed as a result of a failed arm of a triple junction such that rifting ceased in the late Cretaceous [25]. The Niger Delta thus evolved in the late Cretaceous through rift induced tectonics that ended with the opening of the Gulf of Guinea [26].

The coastal sedimentary basins of Nigeria have been through three depositional cycles [27] [28]: first, a midCretaceous marine incursion that ended by mild folding during Santonian; a second cycle that led to the development of the proto-Niger Delta during the Campanian and concluded in a major transgression in the Paleocene. The third sedimentary cycle lasted from Eocene to Recent, leading to the unremitting development of the main Niger Delta. The major thrust of this paper deals with the third cycle, especially from Oligocene to Miocene.

The spatial and temporal distribution of the Niger Delta facies can be grouped into the outcropping and subsurface Tertiary sections Table 1 [27] [29]-[31]. The Akata Formation, Agbada Formation and the youngest Benin Formation make up the subsurface section while the surface and outcropping facies equivalents are respectively, the Imo Formation, Ameki Formation, Ogwashi-Asaba Formation and Benin Formation [32]. The Imo Formation (Paleocene to early Eocene) is known to exhibit blue-grey shales with sand lenses, marls and fossiliferous limestones. The Ameki Formation (Eocene to early Oligocene), sometimes referred to as the Ameki Group [33] is characterized by calcareous clays and silts with thin shelly limestone, rich in foraminifera, also mainly sands with minor silt and clay intercalations. Reyment [32] suggested the name Ogwashi-Asaba Formation (also 
Table 1. Comparisonof the facies of present-day with the Teriary units of the Niger Delta (after Maron [29]).

\begin{tabular}{|c|c|c|}
\hline Present Niger Delta & Outcrops of tertiary strain & Subsurface formation \\
\hline NEDECO Report, 1954 & Reyment, 1965 & Short and Stäuble, 1967 \\
\hline $\begin{array}{l}\text { Continental (fluviatile) depo- } \\
\text { sits, mainly sands }\end{array}$ & Benin Formation & $\begin{array}{c}\text { Benin Formation } \\
\text { Afam Clay Member }\end{array}$ \\
\hline $\begin{array}{c}\text { Mixed continental brackish } \\
\text { water and marine deposits, } \\
\text { sands and clays }\end{array}$ & $\begin{array}{l}\text { Ogwashi-Asaba } \\
\text { Formation } \\
\text { Ameki Formation }\end{array}$ & Agbada Formation \\
\hline Marine deposits, mainly clays & Imo shales & Akata Formation \\
\hline
\end{tabular}

the age, Oligocene-Miocene) to replace the "lignite series" of Parkinson [34] and is made up of lignite seams, clay, shales/carbonaceous mudstones and cross-bedded sandstones. The Benin Formation (Oligocene to Recent) is also marked by cross-bedded, coarse-pebbly continental sands, with clay lenses.

\section{Material and Methods}

Eighteen sandstone samples were obtained from active quarry sites located in the Asaba Capital Territory and Ibusa, Figure 1. These representative samples were carefully obtained from different levels of each quarry from the base to the top, Figure 2. A subset of twelve (12) samples out of the sampled masses was reduced to $10 \mathrm{~g}$ of sediments each by coning and quartering and prepared for heavy mineral separation. The samples were thereafter washed separately to remove clay-sized fractions and boiled with $\mathrm{HCl}$ acid (1:1) for 10 minutes to remove iron coatings and cementing material. They were then washed and dried a second time and thus made ready for heavy mineral separation (gravity method). Separation of the heavy from light minerals was done using bromoform $\left(\mathrm{CHBr}_{3}\right)$ as the separating liquid. The extracts of bromoform containing the heavy minerals were rinsed with acetone and thereafter mounted on glass slides. A quantitative estimation [point-counting method of the opaque and non-opaque fractions (ultra-stable and meta-stable groups)] of the heavy minerals present in the sandstones was done by studying them under the binocular petrological microscope at the Petrology Laboratory, Department of Geology, University of Ibadan, Nigeria.

A second subset of six (6) selected samples was air dried, homogenized by coning and quartering and reduced to $10 \mathrm{~g}$. Aliquots of $10 \mathrm{~g}$ of each dried sample were powdered in an agate mortar. Further preparation and analytical procedures of samples are as outlined in Jarvis and Jarvis [35] and Pearce et al. [36].

Major element oxides and trace/rare earth elements (Sc, Be, V, Sr, Y, Zr, and Ba) concentrations were determined by Fusion Inductively Coupled Plasma (FUS-ICP) with a detection limit of $0.001 \%-0.1 \%$. Other trace and rare earth elements were determined by Fusion Mass Spectrometry (FUS-MS) with a detection limit of 0.04 - $30 \mathrm{ppm}$. These two analytical packages gave results that comprised 10 major elements (oxides and loss on ignition), in addition to 18 trace and 14 rare earth elements respectively. These analyses were done at the Activation Laboratories Limited, Ontario, Canada.

\section{Results}

\subsection{Heavy Mineral Petrography}

The heavy mineral assemblage consists of opaque minerals (e.g. haematite), zircon, rutile, tourmaline, garnet, sillimanite and apatite, in decreasing order of abundance displayed in Table 2 and Figure 3. Thus the opaques have the highest proportion of $42 \%$ of the total heavies while the non-opaques, zircon and rutile account for $26 \%$ in equal proportion, followed by tourmaline which is $12 \%$. Garnet, sillimanite and apatite consist of $8 \%, 7 \%$, and $5 \%$ respectively.

Zircon showed prismatic, sub-hedral grains that have prominent crystal faces. It's colourless, exhibiting high relief and birefringence. Modal composition varies from $9.09 \%$ to $17.78 \%$ of the total heavies. Elongated, prismatic, pleochroic, and sub-rounded grains were indicated by tourmaline with colour variations from brown, greenish brown to dark green. Tourmaline modal composition varies from $8.89 \%$ to $13.95 \%$ of the total heavies. Rutile is reddish brown, weakly pleochroic, and with very high relief. Rutile percentage proportion varies from $11.11 \%$ to $18.60 \%$ of the total heavies. Garnet was identified as colourless to light purple, sub-angular and high 


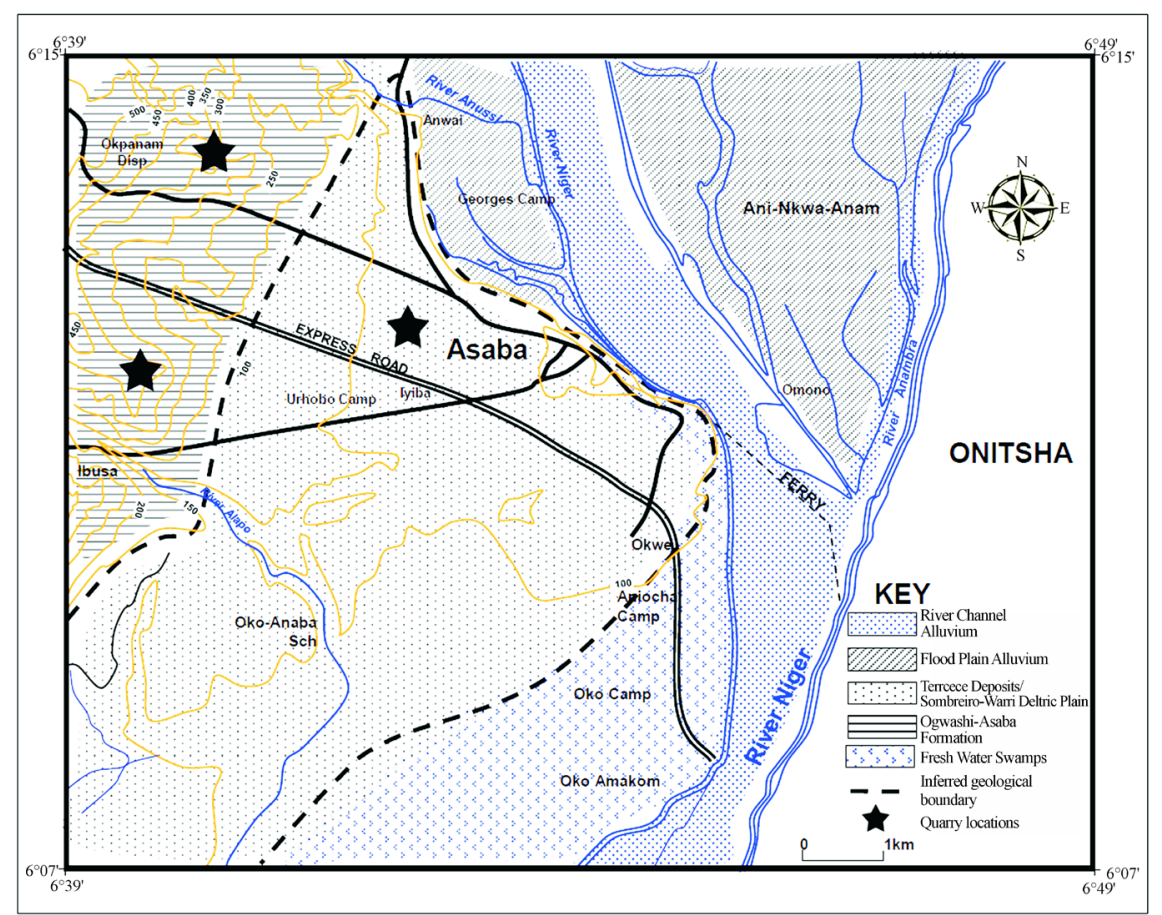

Figure 1. Sample locations on a geological map of Asaba and surrounding areas (modified after Akpoborie et al. [1]).

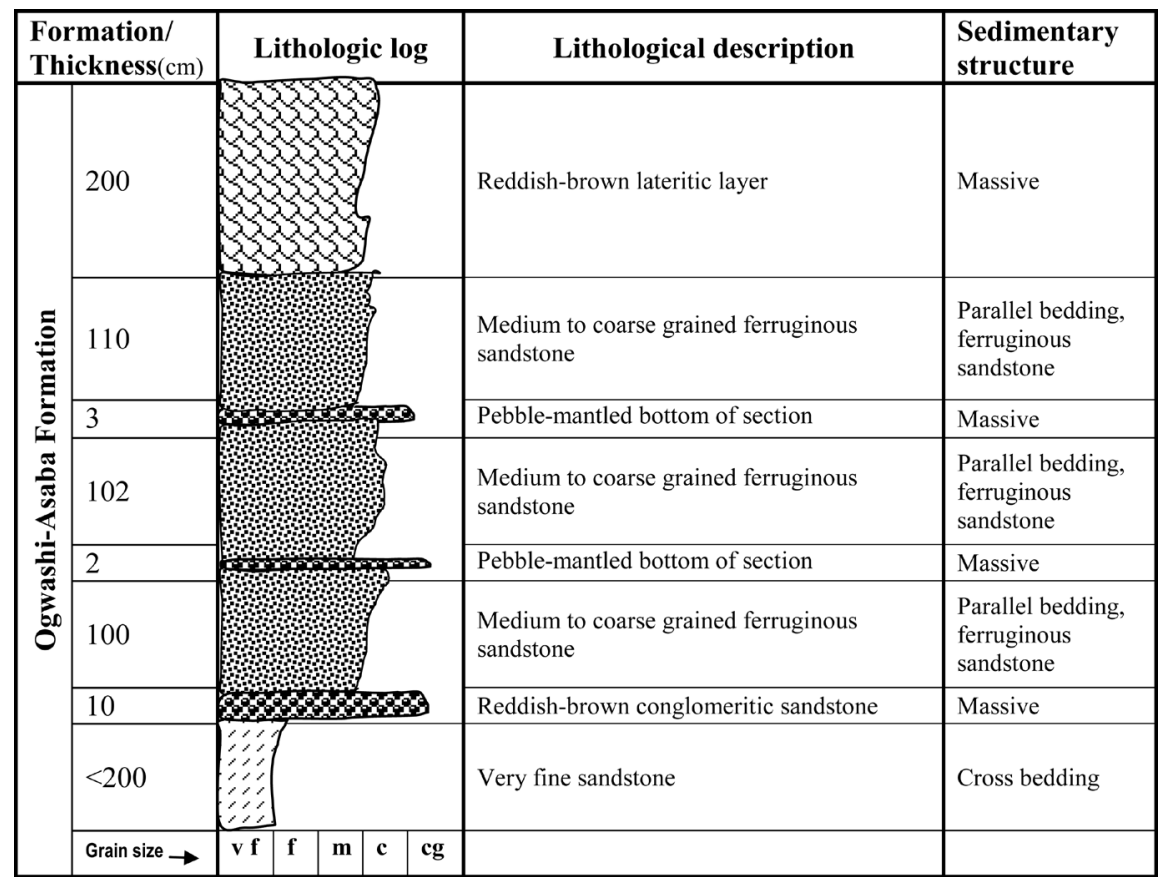

Figure 2. A representative lithological section of the Ogwashi-Asaba Formation observed at Ibuse quarry site.

relief. Apatite is usually colourless with moderate relief. The modal composition of apatite ranges from $3.03 \%$ to $7.14 \%$ while the modal percentage composition of garnet varies from $4.76 \%$ to $11.62 \%$ of total heavies.

Estimates of the Z.T.R. mineralogical maturity indices [36] derived as the ratio of the combined modal composition of zircon $(Z)$, tourmaline $(T)$, and rutile $(R)$ to that of the transparent, non-micaceous and detrital heavy 


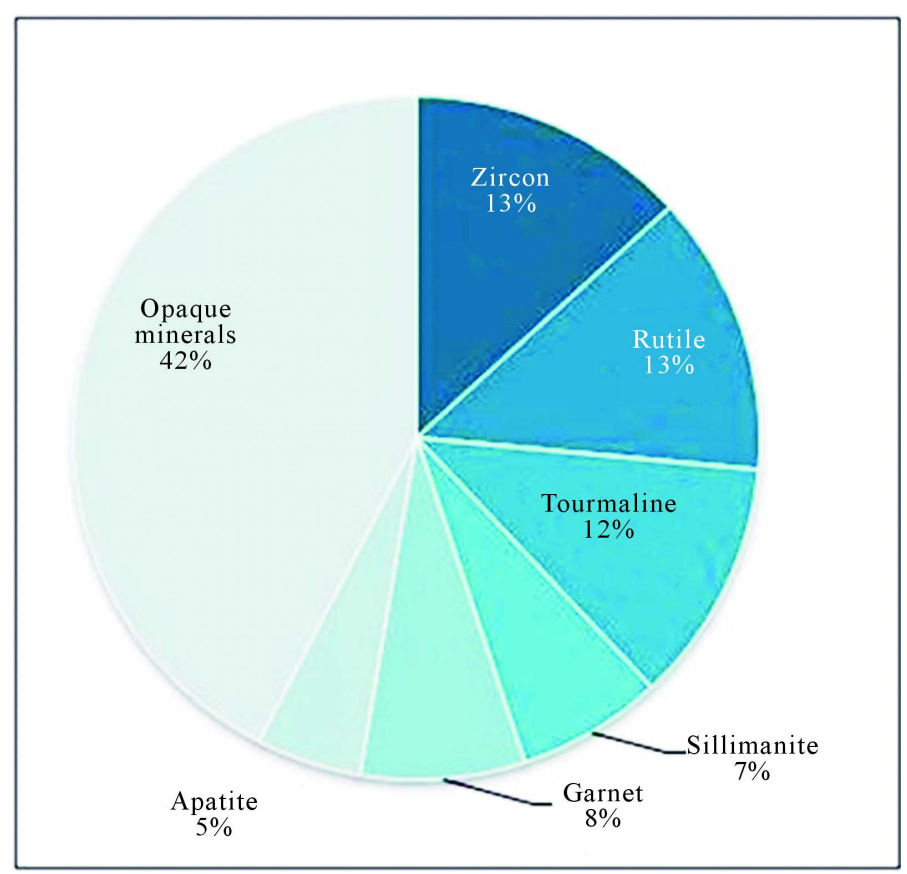

Figure 3. Relative proportions of heavy minerals in the sanstones of the study area.

Table 2. Relative proportions of heavy ninerals (in \%) in the sanstones of the Ogwashi-Asaba Formation.

\begin{tabular}{cccccccc}
\hline Sample code & Zircon & Rutile & Tourmaline & Sillimanite & Garnet & Apatite & Opaque minerals \\
\hline IBS L4A & 13.95 & 11.62 & 13.95 & 6.97 & 6.97 & 4.65 & 41.86 \\
IBS_L2D & 12.50 & 12.50 & 10.42 & 8.33 & 6.25 & 4.17 & 45.83 \\
IBS_L5A & 9.30 & 13.95 & 11.63 & 6.97 & 11.62 & 6.97 & 39.53 \\
IBS_L4B & 11.11 & 11.11 & 13.89 & 5.56 & 8.33 & 5.56 & 44.44 \\
IBS_L1B & 9.09 & 12.12 & 9.09 & 6.06 & 6.06 & 3.03 & 54.54 \\
IBS_L2A & 14.63 & 12.19 & 12.19 & 4.87 & 9.76 & 4.88 & 41.46 \\
IBS_L3B & 9.30 & 18.60 & 11.63 & 6.98 & 6.97 & 4.65 & 41.86 \\
IBS_L2C & 16.27 & 13.95 & 11.62 & 6.97 & 9.30 & 4.65 & 37.21 \\
IBS_L4D & 14.28 & 14.28 & 11.90 & 7.14 & 7.14 & 4.77 & 40.47 \\
IBS_L3E & 17.78 & 11.11 & 8.89 & 6.67 & 8.89 & 4.44 & 42.22 \\
IBS_L3A & 14.28 & 14.28 & 9.52 & 7.14 & 4.76 & 7.14 & 42.85 \\
IBS_L1A & 15.90 & 13.63 & 13.63 & 9.09 & 6.82 & 4.54 & 36.36 \\
Average & 13.20 & 13.28 & 11.53 & 6.89 & 7.74 & 4.95 & 42.39 \\
\hline
\end{tabular}

minerals and expressed as percent for each sample (Table 3), range from $58 \%$ to $68 \%$ with an average of $66.99 \%$.

\subsection{Major Element Geochemistry}

The compositions (wt.\% of oxides) of major elements of the representative sandstone samples are presented in Table 4. The clearly quartz-rich sandstones have $\mathrm{SiO}_{2}$ content that range between 71.42 wt\% and 90.84 wt\%. They are also depleted of $\mathrm{TiO}_{2}, \mathrm{MnO}, \mathrm{P}_{2} \mathrm{O}_{5}$, the alkalis $\left(\mathrm{Na}_{2} \mathrm{O}\right.$ and $\left.\mathrm{K}_{2} \mathrm{O}\right)$ and alkali earth elements ( $\mathrm{MgO}$ and $\mathrm{CaO})$. This parallel depletion can be attributed to the weathering conditions in the source area. In contrast the $\mathrm{Fe}_{2} \mathrm{O}_{3}$ and $\mathrm{Al}_{2} \mathrm{O}_{3}$ show high and slight enrichment respectively. Herron's [38] log-log plot of $\left(\mathrm{SiO}_{2} / \mathrm{Al}_{2} \mathrm{O}_{3}\right)$ versus 
Table 3. Percentages of Zircon, Tourmaline, Rutile and Z.T.R. index of sandstones of the Ogwashi-Asaba Formation.

\begin{tabular}{ccccc}
\hline Sample code & Zircon & Tourmaline & Rutile & ZTR index \\
\hline IBS L4A & 24.0 & 24.0 & 20.0 & 68 \\
IBS_L2D & 23.0 & 19.2 & 23.1 & 65 \\
IBS_L5A & 15.4 & 19.2 & 23.1 & 58 \\
IBS_L4B & 20 & 25.0 & 20.0 & 65 \\
IBS_L1B & 20.0 & 20.0 & 26.7 & 67 \\
IBS_L2A & 25.0 & 20.8 & 20.8 & 67 \\
IBS_L3B & 16.0 & 20.0 & 32.0 & 68 \\
IBS_L2C & 25.9 & 18.5 & 22.2 & 67 \\
IBS_L4D & 24.0 & 20.0 & 24.0 & 68 \\
IBS_L3E & 30.8 & 15.4 & 19.2 & 65 \\
IBS_L3A & 25.0 & 16.7 & 25.0 & 67 \\
IBS_L1A & 25.0 & 21.4 & 21.4 & 68 \\
\end{tabular}

Table 4. Major element compositions (wt.\%) for sandstones from the Ogwashi-Asaba Formation [4].

\begin{tabular}{|c|c|c|c|c|c|c|}
\hline \multirow{2}{*}{$\begin{array}{l}\text { Rock type } \\
\text { Sample \# }\end{array}$} & \multicolumn{3}{|c|}{ Ferruginized sandstones } & \multicolumn{3}{|c|}{ Non-ferruginized sandstones } \\
\hline & IBS_L2E & IBS_L3E & IBS_L2B & IBS_L1C & IBS_L2A & IBS_L3B \\
\hline $\mathrm{SiO}_{2}$ & 71.42 & 76.57 & 78.51 & 87.48 & 90.84 & 92.76 \\
\hline $\mathrm{TiO}_{2}$ & 0.294 & 0.033 & 0.041 & 0.119 & 0.177 & 0.098 \\
\hline $\mathbf{A l}_{2} \mathbf{O}_{3}$ & 1.59 & 1.13 & 1.46 & 1.13 & 1.85 & 1.38 \\
\hline $\mathrm{Fe}_{2} \mathrm{O}_{3} *$ & 21.42 & 19.12 & 16.79 & 9.48 & 4.84 & 3.63 \\
\hline MnO & 0.025 & 0.012 & 0.014 & 0.015 & 0.01 & 0.011 \\
\hline MgO & 0.03 & 0.02 & 0.02 & 0.01 & 0.01 & 0.02 \\
\hline $\mathrm{CaO}$ & 0.02 & 0.02 & 0.09 & 0.02 & 0.02 & 0.44 \\
\hline $\mathrm{Na}_{2} \mathrm{O}$ & 0.05 & 0.04 & 0.05 & 0.03 & 0.04 & 0.05 \\
\hline $\mathbf{K}_{2} \mathbf{O}$ & 0.03 & 0.04 & 0.03 & 0.03 & 0.03 & 0.03 \\
\hline $\mathbf{P}_{2} \mathbf{O}_{5}$ & 0.38 & 0.28 & 0.25 & 0.18 & 0.1 & 0.03 \\
\hline LOI & 3.52 & 3.02 & 2.84 & 1.62 & 1.32 & 1.69 \\
\hline Total & 98.78 & 100.3 & 100.1 & 100.1 & 99.24 & 100.1 \\
\hline $\mathrm{MgO}+\mathrm{Fe}_{2} \mathrm{O}_{3} *$ & 21.45 & 19.14 & 16.81 & 9.49 & 4.85 & 3.65 \\
\hline $\mathrm{Fe}_{2} \mathrm{O}_{3} * / \mathrm{K}_{2} \mathrm{O}$ & 714 & 478 & 559.7 & 316 & 161.3 & 121 \\
\hline $\mathrm{CaO}^{*}+\mathrm{Na}_{2} \mathrm{O}$ & 0.0012 & 0.0010 & 0.0016 & 0.0009 & 0.0010 & 0.0016 \\
\hline $\mathrm{Al}_{2} \mathrm{O}_{3} / \mathrm{TiO}_{2}$ & 5.408 & 34.242 & 35.609 & 9.496 & 10.452 & 14.082 \\
\hline $\mathrm{K}_{2} \mathrm{O} / \mathrm{Na}_{2} \mathrm{O}$ & 0.6 & 1.0 & 0.6 & 1.0 & 0.75 & 0.6 \\
\hline $\mathrm{SiO}_{2} / \mathrm{Al}_{2} \mathrm{O}_{3}$ & 44.92 & 67.76 & 53.77 & 77.42 & 49.10 & 67.22 \\
\hline \multicolumn{7}{|l|}{ Moles } \\
\hline $\mathrm{SiO}_{2}$ & 1.1886 & 1.2743 & 1.3065 & 1.4558 & 1.5117 & 1.5437 \\
\hline $\mathbf{A l}_{2} \mathbf{O}_{3}$ & 0.0156 & 0.0111 & 0.0143 & 0.0111 & 0.0181 & 0.0135 \\
\hline $\mathrm{CaO}^{*}$ & 0.0004 & 0.0004 & 0.0008 & 0.0004 & 0.0004 & 0.0008 \\
\hline $\mathrm{Na}_{2} \mathrm{O}$ & 0.0008 & 0.0006 & 0.0008 & 0.0005 & 0.0006 & 0.0008 \\
\hline $\mathbf{K}_{2} \mathbf{O}$ & 0.0003 & 0.0004 & 0.0003 & 0.0003 & 0.0003 & 0.0003 \\
\hline CIA & 91.228 & 88.800 & 88.272 & 90.244 & 93.299 & 87.663 \\
\hline CIW & 92.857 & 91.735 & 89.937 & 92.500 & 94.764 & 89.404 \\
\hline
\end{tabular}

Note: $\mathrm{Fe}_{2} \mathrm{O}_{3} *$ refers to total $\mathrm{Fe}, \mathrm{CaO} *$ represents $\mathrm{Ca}$ in silicate minerals only (i.e., excluding calcite, dolomite and apatite) [46]. An approximate correction for carbonate content was done by assuming reasonable $\mathrm{Ca} / \mathrm{Na}$ ratios in silicate materials [15]. 
$\left(\mathrm{Fe}_{2} \mathrm{O}_{3} / \mathrm{K}_{2} \mathrm{O}\right)$ for the samples is shown in Figure 4, in which sandstones of the study area fall mostly within the Fe sand field.

\subsection{Trace Element Geochemistry}

Concentrations of trace elements and elemental ratios of the sandstones are shown in Table 5. The sandstones are enriched in $\mathrm{Zr}$, with minor enrichment in $\mathrm{Y}, \mathrm{Nb}$, Th, Hf, and $\mathrm{U}$. Ta is depleted. These elements are essential components of heavy minerals such as zircon. They are less common in mafic rocks, but enriched in felsic rocks. Ratios of trace elements such as La/Sc, Th/Sc, Co/Th, Cr/Th, La/Co, Th/Co, Th/Cr, Eu/Eu*, and Eu* in siliciclastic rocks such as sandstones have been used to infer the average provenance composition [14] [39] [40]-[45].

\subsection{Rare Earth Element Geochemistry}

The rare-earth element concentrations of the sandstones are presented in Table 6. Figure 5 indicates their chondrite normalized rare earth element (REE) pattern, marked by light rare earth element (LREE) enrichment and

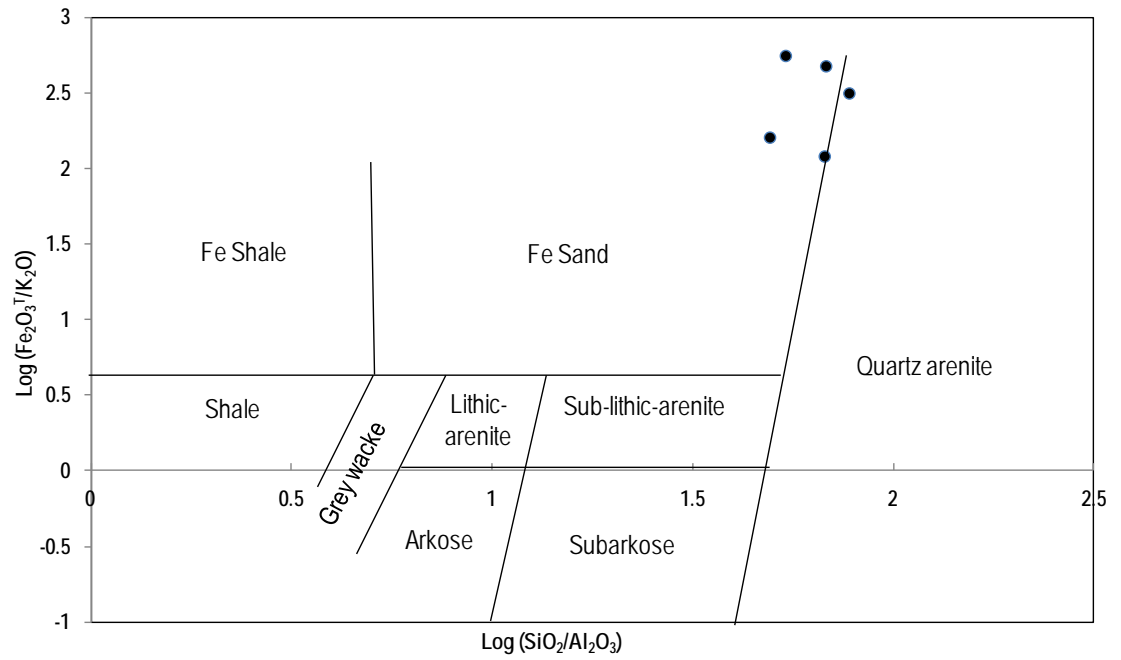

Figure 4. $\mathrm{Log}\left(\mathrm{Fe}_{2} \mathrm{O}_{3} / \mathrm{K}_{2} \mathrm{O}\right)$ versus $\log \left(\mathrm{SiO}_{2} / \mathrm{Al}_{2} \mathrm{O}_{3}\right)$ (after Herron, [38]) for sandstones of the Ogwashi-Asaba Formation.

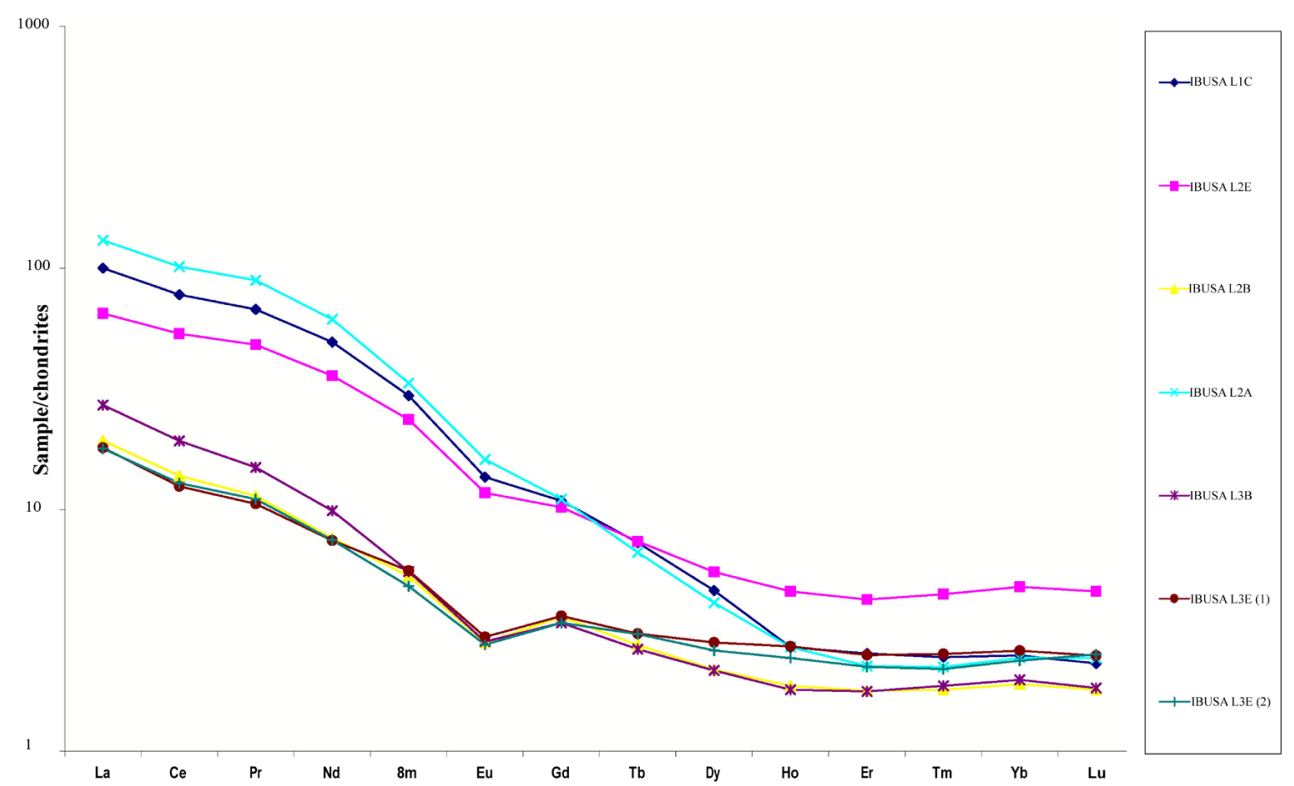

Figure 5. Chondrite normalized REE patterns for sandstones of the Ogwashi-Asaba Formation. 
Table 5. Trace element compositions (ppm) and their ratios for sandstone samples obtained from the Ogwashi-Asaba Formation.

\begin{tabular}{|c|c|c|c|c|c|c|}
\hline \multirow{2}{*}{$\begin{array}{l}\text { Rock type } \\
\text { Sample \# }\end{array}$} & \multicolumn{3}{|c|}{ Ferruginous sandstones } & \multicolumn{3}{|c|}{ Non-ferruginous sandstones } \\
\hline & IBS_L2E & IBS_L3E & IBS_L2B & IBS_L1C & IBS_L2A & IBS_L3B \\
\hline Sc & 4 & 3 & 5 & 3 & 2 & 1 \\
\hline $\mathbf{N i}$ & 19 & 18 & 19 & 17 & 18 & 17 \\
\hline Ga & 3 & 2 & 8 & 2 & 2 & 3 \\
\hline Nb & 10 & 5 & 5 & 7 & 7 & 6 \\
\hline $\mathbf{B a}$ & 31 & 11 & 12 & 44 & 48 & 19 \\
\hline Ta & 0.5 & $<0.1$ & $<0.1$ & 0.1 & 0.2 & 0.2 \\
\hline Co & 5 & 2 & 3 & 2 & 1 & 1 \\
\hline $\mathrm{Cu}$ & 9 & 9.5 & 8.9 & 9.9 & 9.6 & 9.8 \\
\hline $\mathrm{Sr}$ & 12 & 5 & 9 & 16 & 17 & 22 \\
\hline $\mathbf{V}$ & 46 & 28 & 37 & 18 & 12 & 20 \\
\hline Zn & 40 & $<30$ & $<30$ & $<30$ & $<30$ & $<30$ \\
\hline Th & 3.9 & 1.3 & 2.3 & 2.2 & 2.1 & 2.3 \\
\hline $\mathbf{U}$ & 3.7 & 2.8 & 3.4 & 1.8 & 1.3 & 0.9 \\
\hline $\mathrm{Cr}$ & 40 & 20 & 40 & 20 & 17 & 30 \\
\hline $\mathbf{R b}$ & 1.8 & 2 & 1.8 & 1.6 & 1.5 & 1.6 \\
\hline $\mathrm{Zr}$ & 200 & 53 & 54 & 119 & 154 & 84 \\
\hline Hf & 4.4 & 1.2 & 1.3 & 2.6 & 3.4 & 2.0 \\
\hline $\mathrm{Zr} / 10$ & 20 & 5.3 & 5.4 & 1.19 & 1.54 & 8.4 \\
\hline $\mathbf{T h} / \mathbf{U}$ & 1.05 & 0.46 & 0.68 & 1.22 & 1.62 & 2.56 \\
\hline $\mathbf{R b} / \mathbf{S r}$ & 0.15 & 0.40 & 0.20 & 0.10 & 0.09 & 0.07 \\
\hline $\mathrm{Cr} / \mathrm{Th}$ & 10.26 & 15.38 & 17.39 & 9.09 & 8.10 & 13.04 \\
\hline $\mathrm{Cr} / \mathbf{Z r}$ & 0.20 & 0.38 & 0.74 & 0.17 & 0.12 & 0.36 \\
\hline Th/Sc & 0.98 & 0.43 & 0.42 & 0.73 & 1.05 & 2.30 \\
\hline $\mathbf{T h} / \mathbf{Z r}$ & 0.020 & 0.025 & 0.043 & 0.018 & 0.014 & 0.027 \\
\hline La/Th & 5.26 & 4.38 & 2.65 & 14.32 & 19.57 & 3.70 \\
\hline Co/Th & 1.28 & 1.54 & 1.30 & 0.91 & 0.48 & 0.43 \\
\hline $\mathbf{L a} / \mathbf{S c}$ & 5.13 & 1.90 & 1.22 & 10.50 & 20.55 & 8.50 \\
\hline $\mathbf{L a} / \mathbf{C o}$ & 4.10 & 2.85 & 2.03 & 15.75 & 41.10 & 8.50 \\
\hline Th/Co & 0.78 & 0.65 & 0.77 & 1.10 & 2.10 & 2.30 \\
\hline $\mathrm{Th} / \mathrm{Cr}$ & 0.09 & 0.07 & 0.06 & 0.11 & 0.11 & 0.08 \\
\hline $\mathrm{Ba} / \mathrm{La}$ & 1.51 & 1.93 & 1.97 & 1.40 & 1.17 & 2.24 \\
\hline
\end{tabular}


Table 6. Rare earth element concentrations (in ppm) for sandstones obtained from the Ogwashi-Asaba Formation.

\begin{tabular}{|c|c|c|c|c|c|c|}
\hline \multirow{2}{*}{$\begin{array}{c}\text { Rock type } \\
\text { Sample code }\end{array}$} & \multicolumn{3}{|c|}{ Ferruginous sandstones } & \multicolumn{3}{|c|}{ Non-ferruginous sandstones } \\
\hline & IBS_L2E & IBS_L3E & IBS_L2B & IBS_L1C & IBS_L2A & IBS_L3B \\
\hline $\mathbf{L a}$ & 20.5 & 5.7 & 6.1 & 31.5 & 41.1 & 8.5 \\
\hline $\mathrm{Ce}$ & 43.5 & 10.3 & 11.2 & 63.1 & 82.4 & 15.7 \\
\hline Pr & 5.39 & 1.21 & 1.28 & 7.56 & 9.97 & 1.67 \\
\hline Nd & 21.4 & 4.5 & 4.6 & 29.5 & 36.6 & 5.9 \\
\hline Sm & 4.5 & 1.0 & 1.0 & 5.7 & 6.4 & 1.1 \\
\hline Eu & 0.85 & 0.21 & 0.20 & 0.99 & 1.17 & 0.21 \\
\hline Gd & 2.7 & 0.9 & 0.9 & 2.8 & 2.9 & 0.9 \\
\hline $\mathbf{T b}$ & 0.4 & 0.2 & 0.1 & 0.4 & 0.3 & 0.1 \\
\hline Dy & 1.8 & 0.9 & 0.7 & 1.5 & 1.3 & 0.7 \\
\hline Ho & 0.3 & 0.2 & 0.1 & 0.2 & 0.2 & 0.1 \\
\hline Er & 0.9 & 0.5 & 0.4 & 0.5 & 0.5 & 0.4 \\
\hline Tm & 0.14 & 0.08 & 0.06 & 0.08 & 0.07 & 0.06 \\
\hline $\mathbf{Y b}$ & 1.0 & 0.5 & 0.4 & 0.5 & 0.5 & 0.4 \\
\hline $\mathbf{L u}$ & 0.15 & 0.08 & 0.06 & 0.07 & 0.08 & 0.06 \\
\hline $\mathbf{Y}$ & 7.0 & 4.0 & 4.0 & 5.0 & 5.0 & 3.0 \\
\hline $\mathbf{E u} / \mathbf{E} \mathbf{u}^{*}$ & 0.69 & 0.66 & 0.63 & 0.67 & 0.72 & 0.63 \\
\hline Eu* & 1.23 & 0.32 & 0.32 & 1.48 & 1.63 & 0.33 \\
\hline ¿LREE & 95.29 & 22.7 & 24.18 & 137.36 & 176.47 & 32.87 \\
\hline इHREE & 7.39 & 3.36 & 2.72 & 6.05 & 5.85 & 2.72 \\
\hline$\Sigma$ REE & 103.53 & 26.28 & 27.10 & 144.4 & 183.49 & 35.8 \\
\hline LREE/HREE & 12.89 & 6.76 & 8.89 & 22.70 & 30.17 & 12.08 \\
\hline
\end{tabular}

negative Eu anomalies, pointing to the fact that the provenance was mainly continental crustal rocks. The pattern of REE shows appreciable heavy rare earth element (HREE) depletion (a fairly flat HREE pattern).

\section{Discussion and Interpretations}

\subsection{Source-Area Weathering}

The Z.T.R. index calculated for the sandstones is a high (66.99\%) indicating that they are mineralogically matured [37]. Such level of mineralogical maturity is suggestive of either rapid chemical weathering and erosion in high relief source area or a reworking and recycling of pre-existing older sandstones. The depletion of the alkali and alkali earth element and enrichment of $\mathrm{Al}_{2} \mathrm{O}_{3}$ is a consequence of the alteration of igneous and metamorphic rocks during chemical decomposition (weathering). Thus following from Nesbitt and Young [45] and Fedo et al. [46]; and in order to determine the source area weathering history of the Ogwashi-Asaba sandstones, the Chemical Index of Alteration (CIA) and Chemical Index of Weathering (CIW) for all samples were calculated and values are presented in Table 4 and Figure 6. The CIA values range from $87.7 \%$ to 93.3\% (average 89.92\%) and CIW from $89.4 \%$ to $94.7 \%$ (average $91.87 \%$ ) suggestive of the fact that the source region was subjected to intense chemical weathering likely under tropical palaeo-climatic conditions with abundant rainfall. The CIA and CIW values also signify a dominant felsic source and sediment recycling processes [47]. The concentrations of trace elements and REE in the sandstones are indicative of possible sediment weathering, recycling and sorting during transportation and subsequent heavy mineral enrichment. Thus, the high concentrations of $\mathrm{Zr}$ and LREE in the sandstones are indices to heavy mineral enrichment in zircon and monazites respectively. The steep 


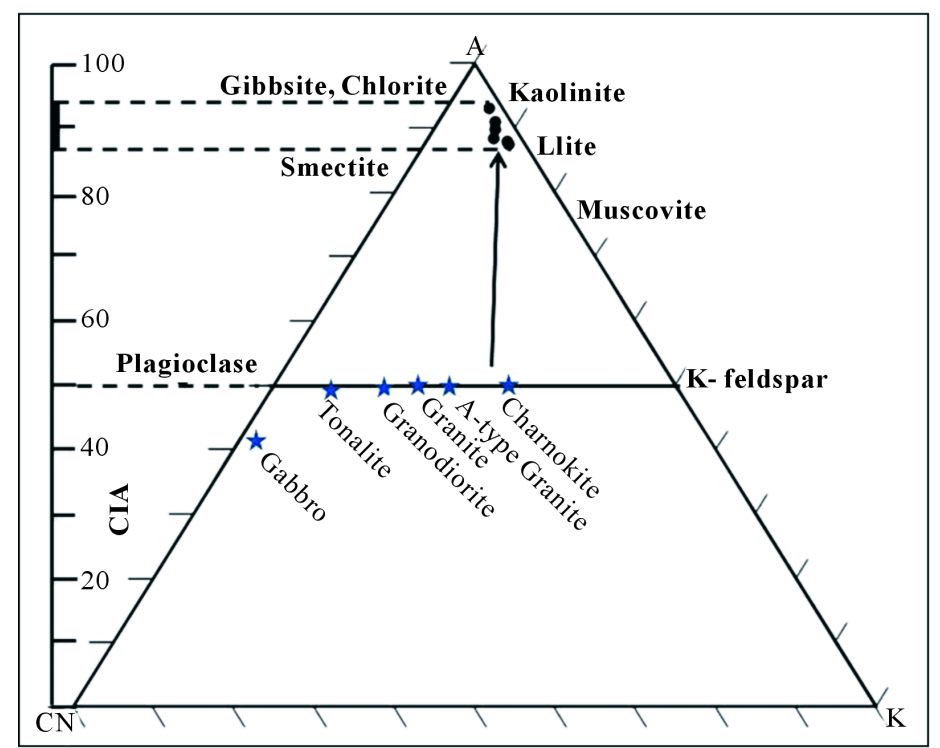

Figure 6. Chemical Index of Alteration (CIA) ternary plot of molecular proportions of $\mathrm{Al}_{2} \mathrm{O}_{3}-\left(\mathrm{CaO} *+\mathrm{Na}_{2} \mathrm{O}\right)-\mathrm{K}_{2} \mathrm{O}$ for sandstones from the Ogwashi-Asaba Formation [4] [45] [46]. The solid arrow shows the actual weathering trend for the samples.

chondrite-normalized REE trend Figure 6, especially the unusually high La concentration is a reflection of possible monazite enrichment.

\subsection{Provenance}

The high percentage of opaque minerals (42\%) is attributable to haematite resulting from the ferruginous sand (average $19.11 \% \mathrm{Fe}_{2} \mathrm{O}_{3}$ ). The presence of zircon, tourmaline, rutile and the suite of opaque heavy minerals (e.g. haematite) is an indication of sediments derived mostly from reworked sources and partly from felsic or acidic igneous rocks.

Major element compositions of sandstones have also been used to determine sedimentary provenance by the application of discriminant function analysis [48] which distinguishes between four fields of sedimentary provenance, namely: mafic igneous (P1), intermediate igneous (P2), felsic igneous (P3) and quartzose sedimentary or recycled (P4). The sandstones of the Ogwashi-Asaba Formation plot in the P3 and P4 fields, Figure 7, indicating mixed source rock (granitic-gneissic or sedimentary) derivation. Furthermore, evidence of passive margin environment of deposition [49] is provided in Figure 8 which shows major element tectonic setting discriminant function diagram for sandstones of the Ogwashi-Asaba Formation. Finally, the major element tectonic setting discriminant diagram in which $\log \left(\mathrm{K}_{2} \mathrm{O} / \mathrm{Na}_{2} \mathrm{O}\right)$ ] is plotted against $\mathrm{SiO}_{2}$ [50] shows that most of the Ogwashi-Asaba sandstones plot in the passive margin depositional area, Figure 9. Passive margin provenance setting consists of recycled sediments that may have been sourced from tectonic uplift of the adjacent sedimentary basins.

Trace elements such as the REE and the high field strength elements (Co, Sc, Hf, Ta, Nb, Ti and Y) are also very useful for provenance studies because of their relatively low mobility during surface sedimentary processes. The negative Eu anomalies shown in Figure 6 and Table 6 suggest provenance from materials that have undergone intra-crustal geochemical differentiation involving plagioclase or orthoclase feldspar acting as a residual phase. The Eu/Eu* values obtained averaged 0.67, which falls within characteristic range of Post Archean Sediments [39].

When elemental ratios from the sandstones of the Ogwashi-Asaba Formation are compared with those described by Condie [40], Armstrong-Altrin et al. [11], Osae et al. [44] and those from other areas (Table 7), the ratios $\mathrm{La} / \mathrm{Sc}, \mathrm{Th} / \mathrm{Sc}, \mathrm{Cr} / \mathrm{Th}$, and $\mathrm{Eu} / \mathrm{Eu}^{*}$ fall within the range of felsic sources and upper continental crust (UCC). Furthermore, the La/Sc, Th/Sc, La/Co, Th/Co, Th/Cr, and Eu/Eu* ratios correspond with similar fractions obtained from felsic and mafic rocks described by Cullers and Podkovyrov, [43] and UCC as described by Taylor 


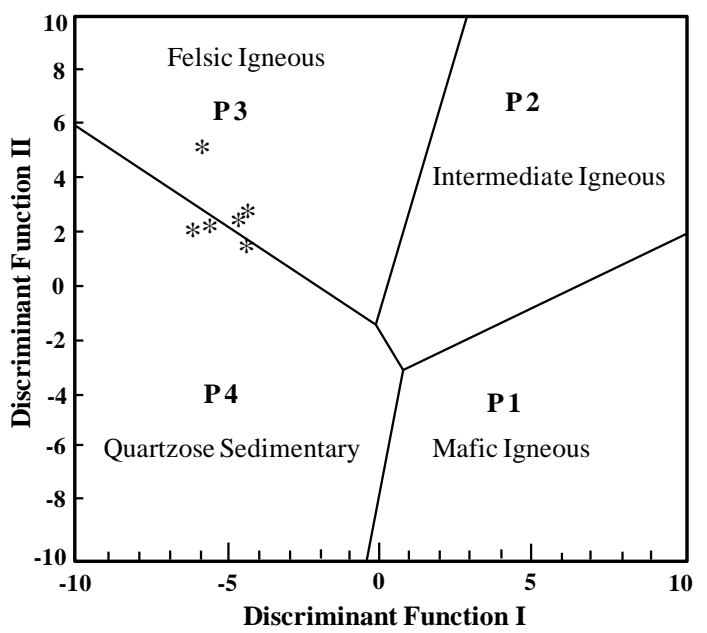

Figure 7. Discriminant function diagram for provenance of the sandstones obtained from the Ogwashi-Asaba Formation.

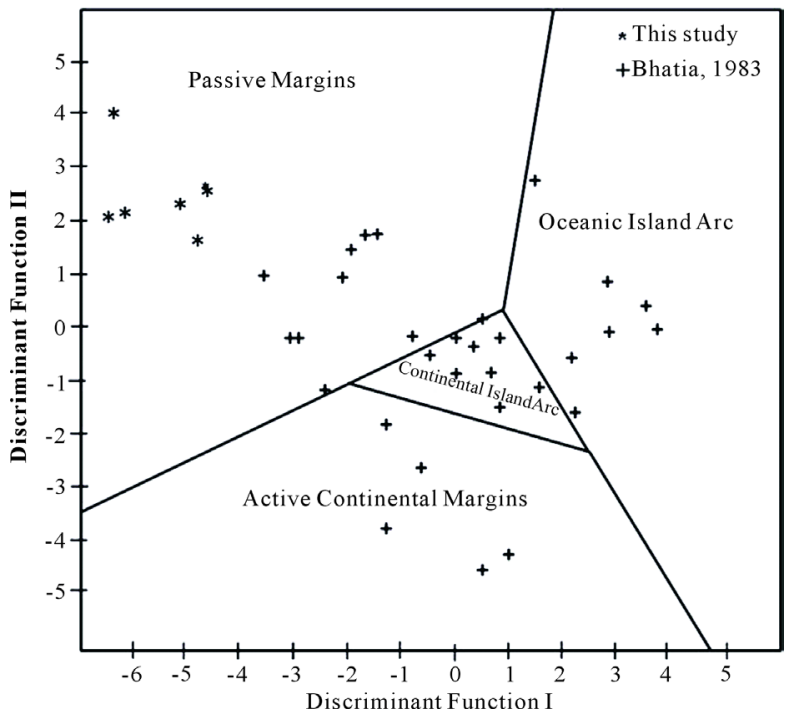

Figure 8. Major element tectonic setting discriminant function diagram for sandstones obtained from the Ogwashi-Asaba Formation.

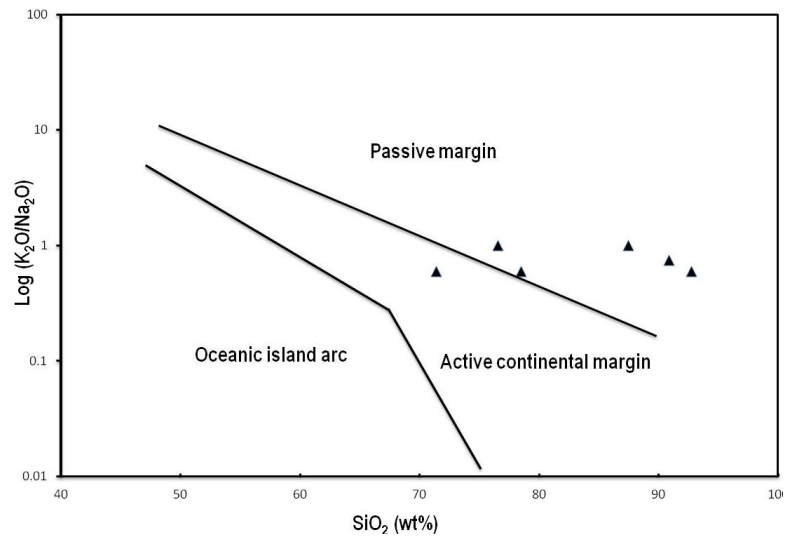

Figure 9. Major element tectonic setting discriminant diagram $\left[\log \left(\mathrm{K}_{2} \mathrm{O} /\right.\right.$ $\mathrm{Na}_{2} \mathrm{O}$ )] versus $\mathrm{SiO}_{2}$ for sandstones of the Ogwashi-Asaba Formation. 
Table 7. Range of elemental ratio of sandstones from Ogwashi-Asaba compared to the ratio in average Proterozoic sandstones, upper continental crust and sandstone derived from felsic rocks and mafic rocks.

\begin{tabular}{|c|c|c|c|c|c|c|}
\hline $\begin{array}{l}\text { Elemental } \\
\text { ratio }\end{array}$ & $\begin{array}{c}\text { Range of Ogwashi-Asaba } \\
\text { sandstone }^{a}\end{array}$ & $\begin{array}{l}\text { Range of sediments } \\
\text { from felsic sources }\end{array}$ & $\begin{array}{l}\text { Range of sediments } \\
\text { from mafic sources }\end{array}$ & $\begin{array}{l}\text { Average Proterozoic } \\
\text { sandstones }\end{array}$ & $\begin{array}{l}\text { Upper continental } \\
\text { crust }(1.6-0.8 \mathrm{Ga})^{\mathrm{c}}\end{array}$ & $\begin{array}{c}\text { Range of Buem } \\
\text { sandstone, } \\
\text { Ghana }^{d}\end{array}$ \\
\hline $\mathrm{La} / \mathrm{Sc}$ & $1.22-20.55$ & $2.50-16.3$ & $0.43-0.86$ & 4.21 & 1.91 & $1.70-12.1$ \\
\hline Th/Sc & $0.42-2.30$ & $0.84-20.5$ & $0.05-0.22$ & 1.75 & 0.71 & $0.53-1.82$ \\
\hline $\mathrm{Cr} / \mathrm{Th}$ & 8.10 - 17.39 & $4.00-15.0$ & $25.0-500$ & 5.71 & 4.46 & $5.74-21.1$ \\
\hline Eu/Eu* & $0.63-0.72$ & $0.40-0.94$ & $0.71-0.95$ & 0.67 & 0.59 & $0.60-1.09$ \\
\hline
\end{tabular}

${ }^{\mathrm{a}}$ This study; ${ }^{\mathrm{b}}[11] ;{ }^{\mathrm{c}}[40] ;{ }^{\mathrm{d}}[44]$.

Table 8. Range of elemental ratios of Ogwashi-Asaba sandstone compared with ratios in similar fractions derived from felsic and mafic rocks [43] and upper continental crust [39].

\begin{tabular}{ccccc}
\hline Elemental ratio & $\begin{array}{c}\text { Range of Ogwashi-Asaba } \\
\text { sandstone }\end{array}$ & $\begin{array}{c}\text { Range of sediments } \\
\text { from felsic sources }\end{array}$ & $\begin{array}{c}\text { Range of sediments from } \\
\text { mafic sources }\end{array}$ & $\begin{array}{c}\text { Upper continental } \\
\text { crust }\end{array}$ \\
\hline $\mathbf{E u} \mathbf{w}^{*}$ & $0.32-1.63$ & $0.40-0.94$ & $0.71-0.95$ & 0.63 \\
$\mathbf{L a} / \mathbf{S c}$ & $1.22-20.55$ & $2.50-16.3$ & $0.43-0.86$ & 2.21 \\
$\mathbf{T h} / \mathbf{S c}$ & $0.42-2.30$ & $0.84-20.5$ & $0.05-0.22$ & 0.79 \\
$\mathbf{L a} / \mathbf{C o}$ & $2.03-41.10$ & $1.80-13.8$ & $0.14-0.38$ & 1.76 \\
$\mathbf{T h} / \mathbf{C o}$ & $0.65-2.30$ & $0.67-19.4$ & $0.04-1.40$ & 0.63 \\
$\mathbf{T h} / \mathbf{C r}$ & $0.06-0.11$ & $0.067-4.0$ & $0.002-0.045$ & 0.13 \\
\hline
\end{tabular}

and McLennan [39] (Table 8).

The REE results, Table 6 also show Eu* values that are attributable to felsic sources with some input from a mafic source and an UCC. This is also supported by the $\mathrm{Cr} / \mathrm{Zr}$ ratios [51] which as shown in Table 5 are all below unity and thus indicative of felsic sources.

\subsection{Tectonic Setting}

Roser and Korsch [50] identified three tectonic settings namely, a passive continental margin (PM), active continental margin (ACM) and oceanic island arc (ARC) on a $\mathrm{K}_{2} \mathrm{O} / \mathrm{Na}_{2} \mathrm{O}-\mathrm{SiO}_{2}$ discrimination diagram, Figure 9 on which sandstone samples from the Ogwashi-Asaba Formation plot mostly in the PM field with some overlap into the ACM field. PM sediments are usually quartz rich sediments sourced from stable continental areas or intra-plate regions and deposited in intra cratonic basins or passive continental margins.

\section{Conclusion}

Heavy mineral data from sandstone layers of the Ogwashi-Asaba Formation show that they are mineralogically mature and derived from both reworked sedimentary and felsic rock sources. Geochemical data also provide indications of the possible palaeo-climate and ancient weathering conditions of the source area, provenance and tectonic setting of deposition. The sandstones are $\mathrm{SiO}_{2}$ and $\mathrm{Fe}_{2} \mathrm{O}_{3}$ rich. CIA and CIW values indicate that the source region was subjected to intense tropical weathering in warm tropical climate. Provenance discrimination diagrams also support the interpretation that the source area was dominated by felsic igneous and recycled sediments. Concentrations of major and trace elements suggest a passive margin setting. It may thus be concluded that the sandstones of the Ogwashi-Asaba Formation were likely derived from the SW and SE Basement Complex rocks (granites, gneisses, etc.) and sedimentary fills of the adjacent basin (Anambra basin and the Benue Trough).

\section{Acknowledgements}

We wish to acknowledge the cooperation of the Lander Brothers, operators of the quarry at Ibusa who granted 
us permission to collect samples at the site as well as the undergraduates from the Department of Geology, Delta State University, Abraka who assisted with the field work.

\section{References}

[1] Akpoborie, I.A., Nfor, B., Etobro, A.A.I. and Odagwe, S. (2011) Aspects of the Geology and Groundwater Conditions of Asaba, Nigeria. Archives of Applied Science Research, 3, 537-550.

[2] Ogala, J.E. (2012) The Geochemistry of Lignite from the Neogene Ogwashi-Asaba Formation, Niger Delta Basin, Southern Nigeria. Earth Science Research Journal, 16, 151-164.

[3] Bassey, C. and Eminue, O. (2012) Petrographic and Stratigraphic Analyses of Palaeogene Ogwashi-Asaba Formation, Anambra Basin, Nigeria. NAFTA, 7-8, 247-254.

[4] Ejeh, O.I., Akpoborie, I.A. and Etobro, A.A.I. (2015) Depositional Setting of Sandstones from the Oligocene-Miocene Ogwashi-Asaba Formation, Niger Delta Basin, Nigeria: Evidence from Grain Size Analysis and Geochemistry. Universal Journal of Geoscience, 3, 71-82.

[5] Boggs Jr., S. and Krinsley, D. (2006) Application of Cathodoluminescence Imaging to the Study of Sedimentary Rocks: Cambridge University Press, Cambridge. http://dx.doi.org/10.1017/CBO9780511535475

[6] Pettijohn, F.J., Potter, P.E. and Siever, R. (1973) Sand and Sandstones. Springer Verlag, New York. http://dx.doi.org/10.1007/978-1-4615-9974-6

[7] Fuchtbauer, H. (1974) Sedimentary Rock. Part II, John Wiley and Sons, New York.

[8] Morton, A.C. (1958) Heavy Mineral in Provenance Studies. In: Zuffa, B.B., Ed., Provenance of Arenites, Reidel Publication Company, New Jersey, 249-277.

[9] Condie, K.C., Lee, D. and Farmer, L. (2001) Tectonic Setting and Provenance of the Neoproterozoic Uinta Mountain and Big Cottonwood Groups, Northern Utah: Constraints from Geochemistry, Nd Isotopes, and Detrital Modes. Sedimentary Geology, 141-142, 443-464. http://dx.doi.org/10.1016/S0037-0738(01)00086-0

[10] Khudoley, A.K., Rainbird, R.H., Stern, R.A., Kropachev, A.P., Heaman, L.M., Zanin, A.M., Podkovyrov, V.N., Belova, V.N. and Sukhorukov, V.I. (2001) Sedimentary Evolution of the Riphean-Vendian Basin of Southeastern Siberia. Precambrian Research, 111, 129-163. http://dx.doi.org/10.1016/S0301-9268(01)00159-0

[11] Armstrong-Altrin, J.S., Lee, Y.I., Verma, S.P. and Ramasamy, S. (2004) Geochemistry of Sandstones from the Upper Miocene Kudankulam Formation, Southern India: Implications for Provenance, Weathering, and Tectonic Setting. Journal of Sedimentary Research, 74, 285-297. http://dx.doi.org/10.1306/082803740285

[12] Carranza-Edwards, A., Kasper-Zubillaga, J.J., Rosales-Hoz, L., Alfredo-Morales, E. and Santa-Cruz, R.L. (2009) Beach Sand Composition and Provenance in a Sector of the Southwestern Mexican Pacific. Revista Mexicana de Ciencias Geológicas, 26, 433-447.

[13] Araújo, C.E.G., Pinéo, T.R.G., Caby, R., Costa, F.G., Cavalcante, J.C., Vasconcelos, A.M. and Rodrigues, J.B. (2010) Provenance of the Novo Oriente Group, Southwestern Ceará Central Domain, Borborema Province (NE-Brazil): A Dismembered Segment of a Magma-Poor Passive Margin or a Restricted Rift-Related Basin? Gondwana Research, 18, 497-513. http://dx.doi.org/10.1016/j.gr.2010.02.001

[14] Cullers, R.L., Basu, A. and Suttner, L. (1988) Geochemical Signature of Provenance in Sand-Size Material in Soils and Stream Sediments Near the Tobacco Root Batholith, Montana, USA. Chemical Geology, 70, 335-348. http://dx.doi.org/10.1016/0009-2541(88)90123-4

[15] McLennan, S.M., Hemming, S., McDaniel, D.K. and Hanson, G.N. (1993) Geochemical Approaches to Sedimentation, Provenance, and Tectonics. In: Johnson, M.J. and Basu, A., Eds., Processes Controlling the Composition of Clastic Sediments, Geological Society of America Special Papers, Vol. 284, 21-40. http://dx.doi.org/10.1130/SPE284-p21

[16] Van De Kamp, P.C. and Leake, B.E. (1995) Petrology and Geochemistry of Siliciclastic Rocks of Mixed Feldspathic and Ophiolitic Provenance in the Northern Apennines, Italy. Chemical Geology, 122, 1-20. http://dx.doi.org/10.1016/0009-2541(94)00162-2

[17] Joo, Y.J., Lee, Y.I. and Bai, Z. (2005) Provenance of the Qingshuijian Formation (Late Carboniferous), NE China: Implications for Tectonic Processes in the Northern Margin of the North China Block. Sedimentary Geology, 177, 97-114. http://dx.doi.org/10.1016/j.sedgeo.2005.02.003

[18] Armstrong-Altrin, J.S. and Verma, S.P. (2005) Critical Evaluation of Six Tectonic Setting Discrimination Diagrams Using Geochemical Data of Neogene Sediments from Known Tectonic Setting. Sedimentary Geology, 177, 115-129. http://dx.doi.org/10.1016/j.sedgeo.2005.02.004

[19] Liu, S., Lin, G., Liu, Y., Zhou, Y., Gong, F. and Yan, Y. (2007) Geochemistry of Middle Oligocene-Pliocene Sandstones from the Nanpu Sag, Bohai Bay Basin (Eastern China): Implications for Provenance, Weathering, and Tectonic Setting. Geochemical Journal, 41, 359-378. http://dx.doi.org/10.2343/geochemj.41.359 
[20] Sinha, S., Islam, R., Ghosh, S.K., Rohtash K. and Sangode, S.J. (2007) Geochemistry of Neogene Siwalik Mudstones along Punjab Re-Entrant, India: Implications for Source Area Weathering, Provenance and Tectonic Setting. Current Science, 92, 1103-1113.

[21] Umazano, A.M., Bellosi, E.S., Visconti, G., Jalfin, A.G. and Melchor, R.N. (2009) Sedimentary Record of a Late Cretaceous Volcanic Arc in Central Patagonia: Petrography, Geochemistry and Provenance of Fluvial Volcaniclastic Deposits of the Bajo Barreal Formation, San Jorge Basin, Argentina. Cretaceous Research, 30, 749-766. http://dx.doi.org/10.1016/j.cretres.2008.12.015

[22] Maravelis, A. and Zelilidis, A. (2010) Petrography and Geochemistry of the Late Eocene-Early Oligocene Submarine Fans and Shelf Deposits on Lemnos Island, NE Greece: Implications for Provenance and Tectonic Setting. Geology Journal, 45, 412-433.

[23] Adediran, S.A., Adegoke, S.O. and Oshin, O.I. (1991) The Continental Sediments of the Nigerian Coastal Basins. Journal of African Earth Sciences, 12, 79-84. http://dx.doi.org/10.1016/0899-5362(91)90059-8

[24] Reyment, R.A. and Tait, E.A. (1972) Faunal Evidence for the Origin of the South Atlantic. Proceedings of 24th International Geological Congress, Montreal, 21-30 August 1972, Section 7, 316-323.

[25] Lehner, P. and De Ruiter, P.A.C. (1977) Structural History of Atlantic Margin of Africa. American Association of Petroleum Geologists Bulletin, 61, 961-981.

[26] Whiteman, A. (1982) Nigeria: Its Petroleum Geology, Resources and Potential. I and II. Graham and Trotman Ltd., London. http://dx.doi.org/10.1007/978-94-009-7361-9

[27] Short, K.C. and Staüble, A.J. (1967) Outline Geology of the Niger Delta. American Association of Petroleum Geologists Bulletin, 51, 761-779.

[28] Hoque, M. (1977) Petrographic Differentiation of Tectonically Controlled Cretaceous Sedimentary Cycles, Southeastern Nigeria. Sedimentary Geology, 17, 235-245. http://dx.doi.org/10.1016/0037-0738(77)90047-1

[29] Maron, P. (1969) Stratigraphical Aspects of the Niger Delta. Journal of Mining and Geology, 4, 3-12.

[30] Wright, J.B., Hastings, D.A., Jones, W.B. and Williams, H.R. (1985) Geology and Mineral Resources of West Africa. George Allen and Unwin, London.

[31] NEDECO (1954) Western Niger Delta: Report on Investigation. NEDECO, The Hague, 143.

[32] Reyment, R.A. (1965) Aspects of Geology of Nigeria. University of Ibadan Press, Nigeria.

[33] Nwajide, C.S. (2013) Geology of Nigeria’s Sedimentary Basins. CSS Bookshop Ltd., Lagos, 1-565.

[34] Parkinson, J. (1907) The Post-Cretaceous Stratigraphy of Southern Nigeria. Quarterly Journal of Geological Society London, 63, 311-320. http://dx.doi.org/10.1144/GSL.JGS.1907.063.01-04.19

[35] Jarvis, I. and Jarvis, K.E. (1995) Plasma Spectrometry in Earth Sciences: Techniques, Applications and Future Trends. In: Jarvis, I. and Jarvis, K.E., Eds., Plasma Spectrometry in Earth Sciences, Chemical Geology, 95, 1-33.

[36] Pearce, T.J., Besly, B.M., Wray, D.S. and Wright, D.K. (1999) Chemostratigraphy: A Method to Improve Interwell Correlation in Barren Sequences-A Case Study Using Onshore Duckmantian/Stephanian Sequences (West Midlands, U.K.). Sedimentary Geology, 124, 197-220. http://dx.doi.org/10.1016/S0037-0738(98)00128-6

[37] Hubert, J.F. (1962) A Zircon-Tourmaline-Rutile Maturity Index and Independence of Heavy Mineral Assemblage with Gross Composition and Texture of Sandstones. Journal of Sedimentary Petrology, 33, 450-460.

[38] Herron, M.M. (1988) Geochemical Classification of Terrigenous Sands and Shales from Core or Log Data. Journal of Sedimentary Petrology, 58, 820-829.

[39] Taylor, S.R. and McLennan, S.M. (1985) The Continental Crust: Its Composition and Evolution. Blackwell Scientific, Oxford.

[40] Condie, K.C. (1993) Chemical Composition and Evolution of the Upper Continental Crust: Contrasting Results from Surface Samples and Shales. Chemical Geology, 104, 1-37. http://dx.doi.org/10.1016/0009-2541(93)90140-E

[41] Cullers, R.L. (1994) The Controls on the Major and Trace Element Variation of Shales, Siltstones and Sandstones of Pennsylvanian-Permian Age from Uplifted Continental Blocks in Colorado to Platform Sediments in Kansas, USA. Geochimica et Cosmochimica Acta, 58, 4955-4972. http://dx.doi.org/10.1016/0016-7037(94)90224-0

[42] Cullers, R.L. (1995) The Controls on the Major and Trace Element Evolution of Shales, Siltstones and Sandstones of Ordovician to Tertiary Age in Wet Mountain Region, Colorado, USA. Chemical Geology, 123, 107-131. http://dx.doi.org/10.1016/0009-2541(95)00050-V

[43] Cullers, R.L. and Podkovyrov, V.N. (2000) Geochemistry of the Mesoproterozoic Lakhanda Shales in Southeastern Yakutia, Russia: Implications for Mineralogical and Provenance Control, and Recycling. Precambrian Research, 104, 77-93. http://dx.doi.org/10.1016/S0301-9268(00)00090-5

[44] Osae, S., Asiedu, D.K., Banoeng-Yakubu, B., Koeberl, C. and Dampare, S.B. (2006) Provenance and Tectonic Setting 
of Late Proterozoic Buem Sandstones of southeastern Ghana; Evidence from Geochemistry and Detrital Modes. Journal of African Earth Science, 44, 85-96. http://dx.doi.org/10.1016/j.jafrearsci.2005.11.009

[45] Nesbitt, H.W. and Young, G.M. (1982) Early Proterozoic Climates and Plate Motions Inferred from Major Element Chemistry of Lutites. Nature, 299,715-717. http://dx.doi.org/10.1038/299715a0

[46] Fedo, C.M., Nesbitt, H.W. and Young, G.M. (1995) Unravelling the Effects of Potassium Metasomatism in Sedimentary Rocks and Paleosols, with Implications for Palaeo-Weathering Conditions and Provenance. Geology, 23, 921-924. http://dx.doi.org/10.1130/0091-7613(1995)023<0921:UTEOPM>2.3.CO;2

[47] Nesbitt, H.W., Markovics, G. and Price, R.C. (1980) Chemical Processes Affecting Alkalis and Alkali Earths during Continental Weathering. Geochimica et Cosmochimica Acta, 44, 1659-1666. http://dx.doi.org/10.1016/0016-7037(80)90218-5

[48] Roser, B.P. and Korsch, R.J. (1988) Provenance Signature of Sandstone-Mudstone Suites Determined Using Discriminant Function Analysis of Major Element Data. Chemical Geology, 67, 119-139. http://dx.doi.org/10.1016/0009-2541(88)90010-1

[49] Bhatia, M.R. (1983) Plate Tectonics and Geochemical Composition of Sandstone. The Journal of Geology, 91, 611627. http://dx.doi.org/10.1086/628815

[50] Roser, B.P. and Korsch, R.J. (1986) Determination of Tectonic Setting of Sandstone-Mudstone Suites Using SiO 2 Content and $\mathrm{K}_{2} \mathrm{O} / \mathrm{Na}_{2} \mathrm{O}$ Ratio. The Journal of Geology, 94, 635-650. http://dx.doi.org/10.1086/629071

[51] Wronkiewicz, D.J. and Condie, K.C. (1989) Geochemistry and Provenance of Sediments from the Pongola Supergroup, South Africa: Evidence for 3.0 Ga Old Continental Craton. Geochimica et Cosmochimica Acta, 53, 1537-1549. http://dx.doi.org/10.1016/0016-7037(89)90236-6 